\title{
Academic Achievement and Individual Differences in the Learning Processes of Basic Skills Students in the University
}

\author{
Garolym d. Moss \\ Southern Ilinois University at Carbondale
}

\begin{abstract}
This study analyzed the relationship between the academic achievement and information-processing habits of basic skills students in the university. Academic achievement was measured by grade-point average (GPA) and American College Testing Program Assessment ( $\mathrm{ACT}$ ) scores. Information-processing habits were determined by the Inventory of Learning Processes (ILP). There was no significant difference in the ILP profiles of high-and lowachieving basic skills students, whether they were grouped by ACT or GPA. Study Methods was the only scale that showed a significant correlation with academic achievement-namely, a negative correlation with $A C T$. A path analysis indicated that the effect of Study Methods on GPA is indirect, as mediated by ACT. Since ACT assesses prior achievement (i.e., high-school performance), it appears that learning style has an effect prior to college entrance. Basic skills students with low ACT scores tend to substitute conventional study methods for deep elaborative processing, but these students are low achievers in college, as indicated by their GPA. A multivariate analysis of variance showed no significant sex or ethnic differences in information-processing habits. Evidently, a low achiever is a low achiever regardless of sex or ethnicity.
\end{abstract}

Schmeck and Grove (1979) found significant differences in the information-processing habits of high- and low-achieving college students. High-achieving students seemed to be more suc-

APPLIED PSYCHOLOGICAL MEASUREMENT Vol.6. No. 3. Summer 1982, pp. 291-296

(C) Copyright 1982 A pplied Psychological Measurement Inc. 0146-6216/82/030291-06\$1.30 cessful at processing information in depth, organizing and fitting it into a personal framework, and retaining factual details. Low-achieving students, however, seemed to substitute conventional study methods for in-depth processing of information.

Basic skills students are low achievers enrolled in the university. These students have American College Testing Program Assessment (ACT) scores lower than required for regular university admission. They are usually required to take basic skills courses in reading, writing, and mathematics before being admitted to regular college courses.

The purpose of this study was to determine how the learning processes of basic skills students in the university were related to their academic achievement and to determine if sex or ethnic origin made a significant difference in their information-processing habits.

So that comparisons could be drawn, the design of the study was modeled on Schmeck and Grove's (1979) study. Schmeck and Grove used the Inventory of Learning Processes (ILP) developed by Schmeck, Ribich, and Ramanaiah (1977) to analyze the effect of the informationprocessing habits of regular college students upon their academic performance. The ILP was also used in the present study. In the Schmeck and Grove (1979) study, regular college students were divided into high- and low-achieving 
groups by grade-point average (GPA) and ACT, and this group division was used in the present study.

Method

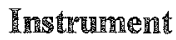

The ILP is a self-report inventory of 62 truefalse statements divided among four scales as follows:

Synthesis-Analysis (SA), 18 items;

Elaborative Processing (EP), 14 items;

Fact Retention (FR), 7 items; and

Study Methods (SM), 23 items.

These processes are described by Schmeck and Ribich (1978) as follows: SA, "the amount of time and energy that the individual was willing to devote to making semantic or categorical judgments regarding new information" (p. 551); EP, "the extent to which an individual is willing to translate new information into personal mediators, images, and examples and to fit it into a personal organizational framework" ( $p$. 552); FR, "an individual's propensity for storing detailed, factual information" (p. 552); and SM, "review[ing] regularly, read[ing] all assignments, attend[ing] all lectures, and generally 'study'[ing] a lot"' (p. 552).

\section{Subjectss}

The subjects in this study were basic skills students enrolled in a developmental reading course at a large midwestern university. The ILP was given to these students at the beginning of the semester. Only students for whom complete information was available were included in the study. The sample contained 174 females and 140 males: 128 white, 172 black, and 14 other. ACT scores submitted with students' applications for university admission and GPA for the first semester's work were obtained from the Records Office. To protect students' privacy, this information was acquired by student identi- fication numbers rather than by names, and the data, including ILP scores, were coded on data processing cards.

\section{Resullis}

Two separate multivariate analyses of variance were conducted-one using GPA, the other using $\mathrm{ACT}$-to compare high-and low-achieving groups in terms of their ILP scores. The median used for dividing by GPA was 2.17; the median for dividing by $\mathrm{ACT}$ was 11.69. The MANOVA program of Statistical Analysis System (SAS) was used for the multivariate analysis of variance. Table 1 presents the ILP means and standard deviations for the groups. (By coincidence, the number of low achievers in the GPA group was the same as the number of high achievers in the ACT group.) For comparison, the Schmeck and Grove (1979) results are also presented in Table 1. No significant differences were found in the ILP profiles of high and low achievers, whether the groups were based on GPA or ACT. Schmeck and Grove (1979), on the other hand, found significant differences between high and low achievers among regular college students for three of the four ILP scales: SA, FR, and EP. These differences occurred whether the groups were based on GPA or ACT. High and low achievers in the basic skills groups scored lower on $\mathrm{SA}, \mathbb{F R}$, and $\mathbb{E P}$ than the low achievers in the Schmeck and Grove (1979) study. However, basic skills groups scored higher than regular college groups on SM. These results were the same whether the groups were divided by GPA or ACT.

Pearson product-moment correlations were computed among all the variables. All zeroorder correlations are given in Table 2, including those for Schmeck and Grove (1979). Two results were similar to the Schmeck and Grove (1979) study. There was a significant positive correlation among the four ILP scales and a significant negative correlation of SM with ACT. Other results differed. Schmeck and Grove (1979) found significant positive correlations for 
Table 1

ILP Means and Standard Deviations of High and Low Achievers by GPA and ACT Scores

\begin{tabular}{|c|c|c|c|c|c|c|c|c|c|}
\hline \multirow{2}{*}{ Group \& Study } & \multirow[b]{2}{*}{$\mathrm{N}$} & \multicolumn{2}{|c|}{ SA } & \multicolumn{2}{|c|}{ SM } & \multicolumn{2}{|c|}{ FR } & \multicolumn{2}{|l|}{ EP } \\
\hline & & Mean & $\overline{S D}$ & Mean & $\overline{S D}$ & Mean & $\overline{\mathrm{SD}}$ & Mean & $\mathrm{SD}$ \\
\hline \multicolumn{10}{|l|}{ GPA Group } \\
\hline \multicolumn{10}{|l|}{ LOW GPA } \\
\hline Basic Ski11s & 163 & 9.82 & 2.87 & 12.36 & 2.92 & 3.39 & 1.27 & 8.53 & 2.40 \\
\hline Schmeck \& Grove & 395 & 10.40 & 4.03 & 10.15 & 4.35 & 4.26 & 1.81 & 9.80 & 2.55 \\
\hline \multicolumn{10}{|l|}{ High GPA } \\
\hline Basic Skills & 151 & 9.53 & 2.87 & 11.83 & 2.78 & 3.44 & 1.15 & 8.05 & 2.33 \\
\hline Schmeck \& Grove & 395 & 12.58 & 3.83 & 10.57 & 3.94 & 5.11 & 1.58 & 10.53 & 2.66 \\
\hline \multicolumn{10}{|c|}{ F-Ratio } \\
\hline Basic Ski11s & & .51 & & .12 & & .52 & & .68 & \\
\hline Schmeck \& Grove & & $57.79:$ & & 2.04 & & $54.08 *$ & & $15.60 *$ & \\
\hline \multicolumn{10}{|l|}{ ACT Group } \\
\hline \multicolumn{10}{|l|}{ Low ACT } \\
\hline Basic Skills & 151 & 9.68 & 3.17 & 12.39 & 3.06 & 3.40 & 1.31 & 8.42 & 2.65 \\
\hline Schmeck \& Grove & 395 & 10.46 & 4.15 & 10.74 & 4.29 & 4.48 & 1.77 & 9.97 & 2.65 \\
\hline \multicolumn{10}{|l|}{ High $\mathrm{ACT}$} \\
\hline Basic Skills & 163 & 9.67 & 2.57 & 11.83 & 2.65 & 3.43 & 1.12 & 8.18 & 2.10 \\
\hline Schmeck \& Grove & 395 & 12.49 & 3.75 & 9.97 & 3.97 & 4.88 & 1.71 & 10.36 & 2.59 \\
\hline \multicolumn{10}{|l|}{$F-$ Ratio } \\
\hline Basic Skills & & .00 & & 2.98 & & .05 & & .80 & \\
\hline Schmeck \& Grove & & 51.05 & & $7.04 \%$ & & $10.54 \%$ & & $4.35 \%$ & \\
\hline \multicolumn{10}{|l|}{ A11 Subjects } \\
\hline Basic Skills & 314 & 9.98 & 2.87 & 12.10 & 2.86 & 3.41 & 1.21 & 8.30 & 2.38 \\
\hline Schmeck \& Grove & 790 & 11.49 & 4.08 & 10.36 & 4.15 & 4.68 & 1.75 & 10.17 & 2.63 \\
\hline
\end{tabular}

SA, FR, and EP with academic achievement, whereas in this study these correlations were negative and not statistically significant.

The MANOVA program of SAS was used to analyze sex and ethnic differences in the information-processing habits of basic skills students. Table 3 presents the ILP means and standard deviations for sex and ethnic groups. Neither ethnic origin nor sex had a significant effect. The Schmeck and Ribich (1978) and Schmeck et al. (1977) studies also found that sex had no significant relationship with ILP profiles of regular college students. (Ethnic differences were not examined.)
Schmeck and Grove (1979) used path analysis procedures to determine the causal relationships between the ILP scales and GPA on the one hand and ACT on the other. A path analysis was conducted for the data in this study as well. Figure 1 presents a path analysis diagram and path coefficients (standardized regression coefficients), and for comparison includes the Schmeck and Grove (1979) results. Statistically nonsignificant paths were deleted in their study, but all coefficients were included here. The only significant relationships found were an indirect relationship between SM and GPA, as mediated by $\mathrm{ACT}$, and a direct relationship be- 
Table 2

Intercorrelations Among the Achievement Measures and the Scales of the ILP

\begin{tabular}{llllll}
\hline \hline Variable & GPA $^{2}$ & ACT & SA & SM & FR \\
\hline ACT & $.48 * *$ & & & & \\
\multirow{2}{*}{ SA } & $(.35 * *)$ & & & & \\
& -.07 & -.03 & & & \\
SM & $(.23 * *)$ & $(.30 * *)$ & & & \\
FR & -.08 & $-.12 * *$ & $.36 * *$ & & \\
& $(.06)$ & $(-.09 *)$ & $(.25 * *)$ & & \\
EP & -.01 & -.01 & $.26 * *$ & $.22 * *$ & \\
& $(.20 * *)$ & $(.14 * *)$ & $(.38 * *)$ & $(.25 * *)$ & \\
& -.04 & -.02 & $.39 * *$ & $.39 * *$ & $.20 * *$ \\
& $(.15 * *)$ & $(.08 *)$ & $(.43 * *)$ & $(.34 * *)$ & $(.12 *)$ \\
\hline
\end{tabular}

${ }^{a}$ Schmeck \& Grove (1979) results are in parentheses. $* \underline{p}<.05 ; * * \underline{p}<.01$.

Table 3

ILP Means and Standard Deviations of Sex and Ethnic Groups in Basic Skills

\begin{tabular}{|c|c|c|c|c|c|}
\hline \multicolumn{6}{|l|}{ Group and } \\
\hline Statistic & $\mathrm{N}$ & $\mathrm{SA}$ & SM & FR & $E P$ \\
\hline \multicolumn{6}{|l|}{ Sex Group } \\
\hline Female & 174 & & & & \\
\hline Mean & & 9.52 & 12.16 & 3.48 & 8.30 \\
\hline $\mathrm{SD}$ & & 2.92 & 2.77 & 1.20 & 2.21 \\
\hline Male & 140 & & & & \\
\hline Mean & & 9.87 & 12.04 & 3.33 & 8.30 \\
\hline SD & & 2.80 & 3.00 & 1.23 & 2.58 \\
\hline$*$ F-Ratio & & 1.14 & .13 & 1.26 & .00 \\
\hline \multicolumn{6}{|c|}{ Ethnic Group } \\
\hline Black & 172 & & & & \\
\hline Mean & & 9.41 & 12.21 & 3.45 & 8.50 \\
\hline SD & & 3.12 & 3.20 & 1.29 & 2.48 \\
\hline White & 128 & & & & \\
\hline Mean & & 10.00 & 12.02 & 3.43 & 8.02 \\
\hline $\mathrm{SD}$ & & 2.53 & 2.28 & 1.07 & 2.26 \\
\hline Other & 14 & & & & \\
\hline Mean & & 10.14 & 11.57 & 2.93 & 8.36 \\
\hline $\mathrm{SD}$ & & 2.32 & 3.37 & 1.38 & 1.95 \\
\hline Foratio & & 1.73 & .42 & 1.19 & 1.48 \\
\hline \multicolumn{6}{|c|}{ Al1 Subjects 314} \\
\hline Mean & & 9.68 & 12.10 & 3.41 & 8.30 \\
\hline SD & & 2.87 & 2.86 & 1.21 & 2.38 \\
\hline
\end{tabular}


Figure 1

Path Analysis and Path Coefficients (Standardized Regression Coefficients)

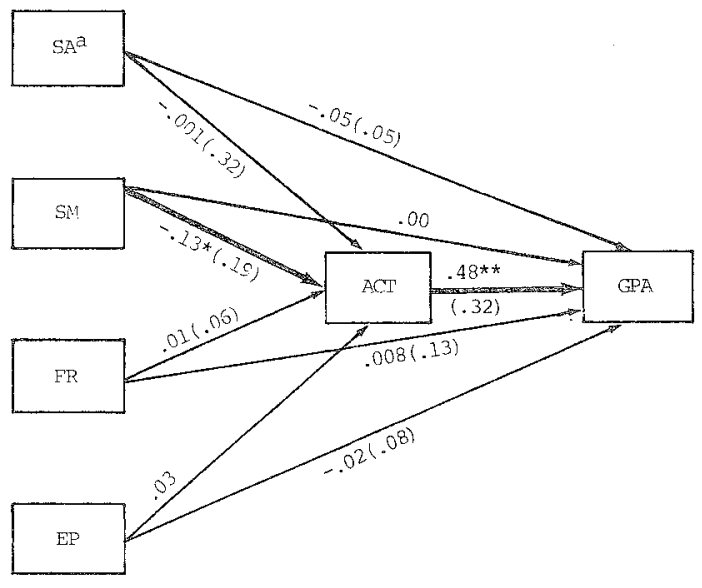

aschmeck \& Grove (1979) results are given in parentheses. Only significant coefficients were given in that study. ${ }^{*} \mathrm{p}<-05 ;{ }^{*} \mathrm{p}<.01$

tween ACT and GPA. Since ACT assesses prior academic achievement (i.e., high-school performance), it appears that learning style has an effect prior to college entrance. Basic skills students with low $\mathrm{ACT}$ scores tend to substitute conventional study methods for deep elaborative processing, but these students are low achievers in college, as indicated by their GPA. These were the only path analysis findings similar to Schmeck and Grove's (1979), except that in their study the coefficient for SM was positive rather than negative. Schmeck and Grove (1979) found significant effects of $\mathrm{SA}, \mathrm{FR}$, and $\mathrm{EP}$ on GPA. In this study no such effects were evident. The path model in Figure 1 accounted for $12 \%$ of the variance of $\mathrm{ACT}$ and $48 \%$ of the GPA variance, whereas the path model in Schmeck and Grove (1979) accounted for $35 \%$ of the variance of ACT and $40 \%$ of the GPA variance.

\section{Discussion}

In contrast to the Schmeck and Grove (1979) findings for regular college students, the ILP scales of $\mathrm{SA}, \mathrm{FR}$, and $\mathrm{EP}$ were not significantly related to ACT or GPA. In short, this study showed no significant relationship, direct or indirect, between learning processes and academic achievement of basic skills students in the university. However, as in Schmeck and Grove (1979), there was a small significant negative relationship between SM and ACT. It would appear from this that the more successful regular and basic skills students were in high school, the less they rely in college upon conventional study methods.

Again, in contrast to Schmeck and Grove (1979), who found that ILP scores differed sig. nificantly for high and low achievers among regular college students, this study found no significant difference in the ILP scores of high- and low-achieving basic skills students. However, high-achieving basic skills students were similar to low-achieving regular college students in their information-processing habits, although their ILP scores, except for SM, were lower.

Neither ethnic origin nor sex affected the information-processing habits of basic skills students. Schmeck and Ribich (1978) and Schmeck et al. (1977) also found that sex had no significant relationship with the information-processing habits of regular college students (they did not examine for ethnic differences). Evidently, a low achiever is a low achiever regardless of sex or ethnicity.

The fact that basic skills students, like lowachieving regular college students, scored higher on SM confirms the conclusion of Schmeck and Ribich $(1978$, p. 551) that "students with low critical thinking ability ... might substitute conventional repetitive study for 'deep processing." "This is an important consideration for those teaching basic skills students, since the improvement of study methods is a typical objective of basic skills programs. As Schmeck and Grove (1979) suggest, study methods aimed at developing critical thinking may result in higher academic achievement. However, if such study methods are to have a significant effect, they should be taught to students prior to their entering the university. 


\section{II: eferences}

Schmeck, R. R., \& Grove, E. Academic achievement and individual differences in learning processes. Applied Psychological Measurement, 1979, 3, 43-49.

Schmeck, R. R., \& Ribich, F. D. Construct validation of the Inventory of Learning Processes. Applied Psychological Measurement, 1978, 2, 551-562.

Schmeck, R. R., Ribich, F. D., \& Ramanaiah, N. Development of a self-report inventory for assessing individual differences in learning processes. $A p^{-}$ plied Psychological Measurement, 1977, I, 413-431.

\section{AcknRowledgrments}

The author is pleased to acknowledge the assistance of Ronald R. Schmeck, who acted as a consultant on this study,

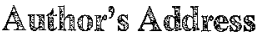

Send requests for reprints or further information to Carolyn Moss, 400 N. Oakland, F-33, Carbondale $1 \mathrm{~L}$ 62901.

Downloaded from the Digital Conservancy at the University of Minnesota, http://purl.umn.edu/93227. 